\title{
WOMEN PARTICIPATION IN LOCAL AUTHORITIES MANAGEMENT IN RURAL AREAS IN POLAND
}

Alina DANILOWSKA, Faculty of Economic Sciences, Warsaw University of Life Sciences, Warsaw, Nowoursynowska str. 166, Warsaw, Poland, warsawalina_danilowska@sggw.pl

\begin{abstract}
The aim of the paper is to evaluate the scope and determinants of women participation in basic local authorities in rural areas in Poland. In the paper the detailed analysis on the problem were carried out on 5\% of women and 5\% of men headed rural gminas. The analysis showed that the women participation in top positions in governing bodies of local communities in Poland is low. It indicates the existence of the severe problem with women promotion to the top positions in decision bodies in politics. The luck of differences in women role betwee rural and urban communities is a very interesting result. Gminas managed by women are rather smaller than gminas administered by men. In many gminas the position of women at the village level is higher than at gmina level. The findings suggest the connection between activity of women at village level and women position as mayor. Moreover, the investigation showed that in rural gminas women prevail in important back-office positions like main secretary of the gmina office and chief aaccountant. So, women are familiar with their gminas problems, are involved in management of them but they don't apply for top positions. It seems that the concept of labyrinth can be applicable to the situation of women in decision making bodies in rural areas in Poland.
\end{abstract}

Keywords: local governments, women in management, glass ceiling, rural areas, rural gmina

\section{INTRODUCTION}

The women participation in economic life is widely accepted in European Union (EU). In 2005 women consisted of $44.4 \%$ EU workers and self-employed persons, and in the next eleven years, their share increased some percentage point to $46.1 \%$ in 2016 (Eurostat 2017). But it is worth to underline that the scope of the women activity in labour market is very differentiated regionally ${ }^{1}$. For example in Greece and Italy the share of women in employment is amounted at $42 \%$, whereas in Latvia and Lithuania it exceeds 50\%. Women are active in political life too. They have had right for vote for about 100 years ${ }^{2}$. Women are members of political parties and take part in their decision bodies. Women are prepared well for such activities. In EU, 32.5\% of women aged 25-64 years achieved tertiary education (level 5-8). For men this indicator is below 30\%. The best situation is in Finland - 50\%, the worst in Romania - 18.2\% (Figure 1). Only in three countries: Germany, Austria and Luxembourg the share of men with tertiary education exceeds that for women. In Netherlands the shares are equal.

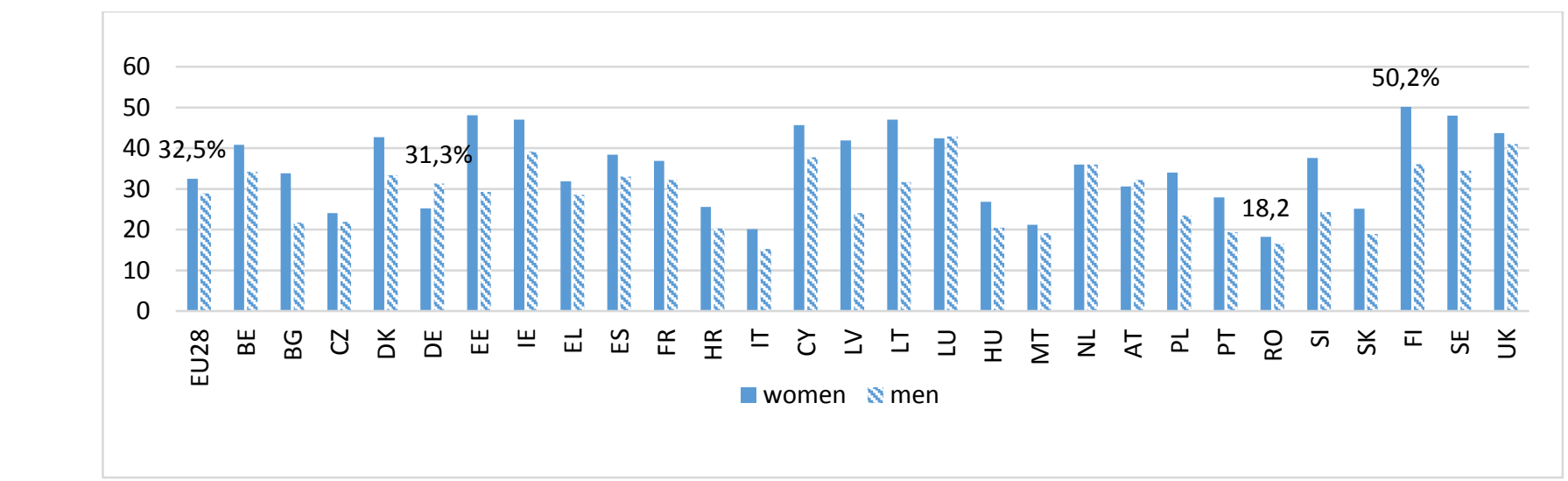

Source: Author's calculation based on Eurostat data (access 30 October 2017)

Figure 1. People in age 25-64 with tertiary education in groups by sex in EU in $2016(\%)$

\footnotetext{
${ }^{1}$ Territorial dimension is connected to cultural dimension strictly.

${ }^{2}$ It was the process. In different countries women got the suffrage in different time.
}

Copyright (C) 2017 The Authors. Published by Aleksandras Stulginskis University. This is an open-access article distributed under the terms of the Creative Commons Attribution License (CC-BY 4.0), which permits unrestricted use, distribution, and reproduction in any medium, provided the original author and source are credited. 
Education-related factors can be treated as an indicators of human capital (Boarini et all 2012). The records on level of education of women and men indicate that the women represent generally higher level of human capital compared to men. So these abilities should be put at the service of economic performance and welfare of the entire society. But data on the role of women in different kind of organizations - economic, political educational and others reveal immense women underrepresentation in top positions in these organisations. According to data for 2015 collected by The European Institute for Gender Equality (2017), only in $14 \%$ of central banks in EU woman was a president or deputy of president and a share of women in a group of members of central bank boards was at $19 . \%$. Women headed $7 \%$ companies listed at stock exchange. The proportion of women in boards of largest listed companies, supervisory board of directors in EU was amounted at $21.7 \%$. A slightly better situation was observed in politics. Share of women on minister position remained at $26.8 \%$, in members of parliament $-27.7 \%$, and in members of regional assemblies $-28 \%$. There were very big difference between countries, for example in Malta women consist of only $3.8 \%$ of boards of the largest listed companies, whereas in France 34,8\%. In the case of members of parliament, the indicators are at 9.7\% for Hungary and $44.4 \%$ for Sweden. For Poland the data regarding politics and economy are beneath the EU's average. In 2016 only one commercial bank in Poland was headed by a woman. Women consisted only $12.05 \%$ of management boards and $14,49 \%$ of supervisory boards of directors of companies listed on main segment of Warsaw Stock Exchange (Sierocka 2017).

Phenomenon of the women underrepresentation on the top positions in economy, politics and other types of activity drew wide public attention in 80ties of XX century. In 1986 G. Hymowitz i T.D. Schellhardt in their article published in The Wall Street Journal used the term ,the glass-ceiling” (Hymowitz G. i Schellhardt T.D. 1986). The paper gained enormous interest and the term ,glass ceiling" has become very popular and rooted in terminology on women discrimination ${ }^{3}$. The term refers to a set of different kinds of barriers the women face during their professional carriers. They do not allow them to take the top positions in organisations where they carry activity in. The word „glass" suggests that women are unware about their real opportunities for promotion because the impediment was not easy for them to see form the distance. The paper indicates that the barriers stem from prejudice of male managers and their preferences not to work with women. The paper triggered great response. Governments and different types of organizations put attention to the problem. Massive research and measures for recognizing the scope, nature and determinant of the phenomenon and sorting out the problem were brought into operations. In the frame of women labour market analysis, in 1992, C. Berheide in a report for the Centre for Women in Government at State University of New York drew attention to the situation of hundreds of thousands of women trapped in low-wage, low-mobility jobs in state and local governments. These women were not so lucky to have "the glass ceiling" as their problem (Berheide 1992). To encapsulate the problem she used term "sticky floors".

In 2007 A. Eagly and L. Carli (2007) in published book proclaimed that barriers to women's advancement became more permeable comparing to time the term "glass ceiling" was coined. They made a severe criticism of the assumptions, suggestions and implications of the "glass ceiling" concept. They arise the questions why have women gained more access to powerful leadership positions how and why do men continue to have fare more access than women do. They offer a new metaphor „Labyrinth" that captures the varied challenges the women faces on their way to leadership. The "labyrinth" contains many barriers some subtle while others quite obvious.

The aim of the paper is to evaluate the scope and determinants of women participation in local governments in rural areas in Poland. The paper concerns some issues: (i) the scope and characteristics of women participation in local governments, (ii) determinants of women participation in local governments.

The problem has many dimensions. As A. Danilowska (2017) underlines, there is not many opportunities in rural areas for professional or social carrier. The list of top positions in a typical gmina is not long and involves: mayor, deputy(ies) of mayor, main secretary of gmina office, main accountant (treasurer), head of gmina council, his or her deputy(ies), councillors, village mayor, chairs of gmina entities like schools or libraries. The people on these positions belong to the local elites.

\section{RESEARCH METHODOLOGY}

The research was carried out using some different methods. The descriptive method was applied to the theory of the phenomenon. The comparative and statistical methods were used for empirical data analyses.

The examination concerns governments of local communities in rural areas in Poland. The basic administrative unit in Poland is called gmina. There are 2478 gminas in Poland. 1555 of them have status of rural gmina, 621 of urbanrural gmina, 236 urban gmina and 66 of town on status gmina (http://administracja.mswia.gov.pl). The gmina as an administrative unit, is managed by the directly elected mayor ${ }^{4}$. Moreover, in each gmina there is a municipal council ${ }^{5}$ that plays role of a legislative and controlling body. It consists of local society representatives and is elected for four years. At the village level, the board of village residents conduct activity. It is headed by mayor of village ${ }^{6}$.

\footnotetext{
${ }^{3}$ The term glass ceiling in print was used already in 1984 by Gay Bryant in the interview published in American Magazine World/Adweek, March 15, 1984 and in her book "The Working Woman Report: Succeeding in Business in the 80's" (Bryant1985) but did not gained popularity. More

conscious and widely noticed use of the term was made in aforementioned Wall Street Journal 32-page special report on "The Corporate Woman" in America (Morgan 2015).

${ }^{4}$ In rural gmina he/she is called wojt, in urban and urban-rural gmina - burmistrz, in town with gmina status- president.

${ }^{5}$ so called "Rada gminy".

${ }^{6}$ In the Polish language soltys.
} 
For the detailed analyses of the problem, $5 \%$ of rural gminas headed by woman and $5 \%$ of rural gminas headed by man were selected randomly from the list of 1555 of rural gminas in Poland published by Ministry of the Interior and Administration Office. Next, the relevant information presented at the gminas' internet websites and at websites of public information bulletin on the participation of women in local government bodies were gathered and analysed. Moreover, the data from European Union Statistic and The European Institute for Gender Equality were used.

Descriptive and comparative methods are the main methods of the investigation. They are supported widely by quantitative analysis.

The paper is organized as follow. In the introduction the short characteristics of the two perspectives on examined problem - glass ceiling and labyrinth concepts - were given. It is followed by the presentation of involvement of women in local level government bodies in EU. The results of the examination carried out by author on the role of women in governing of local communities on rural areas are presented. The investigation considered women occurrence on the top positions in gminas' authority bodies like mayor of gmina, gmina council, village council and determinants of women advancement to top positions in gmina. At the end the conclusion were drown out.

\section{RESULTS OF RESEARCH}

Data on women participation in top positions in local authorities in EU prove that the problem of women underrepresentation exist and is very serious. The figure 2 that refers to the share of women in the group of leaders of local governments in EU countries indicates two issues. Firstly, it shows that the share of women on mayor position (or equivalent) is low and differs noticeably among UE countries. In 2017, the average for EU(28) share of women in a such body is amounted at $15 \%$, but in 18 countries it is below this level. The extremely unfavourable situation is in Czech Republic, Romania and Greece. In these countries the indicator is beneath 5\%. Relatively much more higher levels of the indicators are for Sweden, Latvia and Slovakia. Poland with the share at about $11 \%$ locates at the end of the ranking.

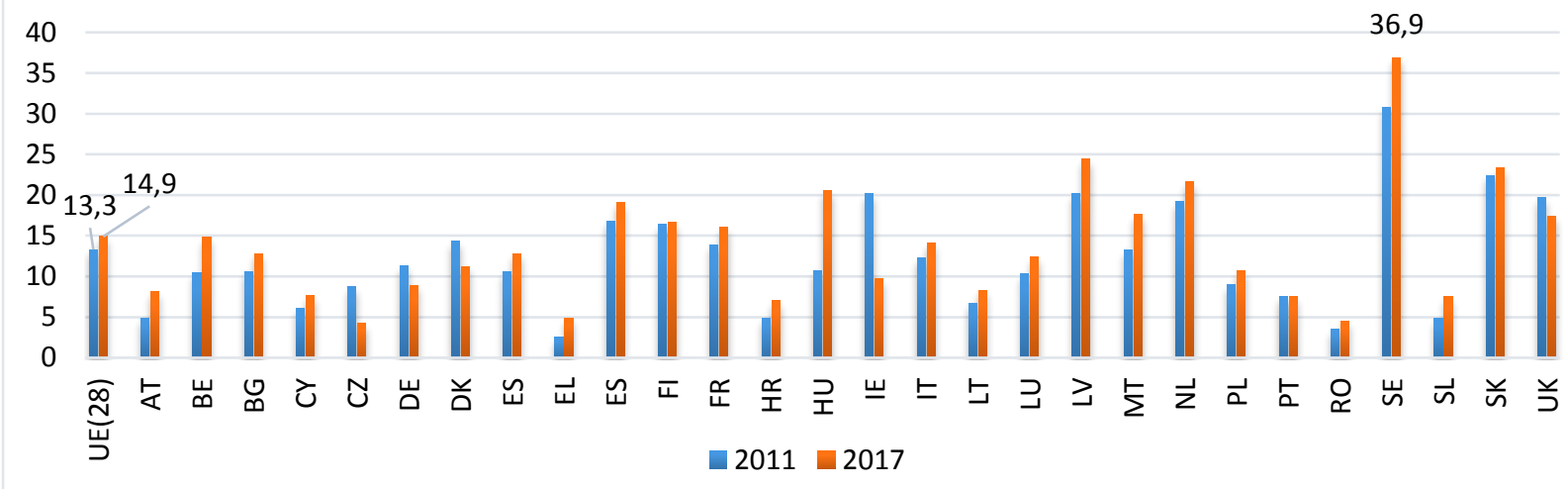

Source. http://eige.europa.eu/gender-statistics/dgs/indicator/wmidm_pol_parl_wmid_locpol

Figure 2. The share of women on positon of a mayor or other leader of the local government in 2011 and 2017 in EU (\%)

Second conclusion from the analysis of the figure 2 is more optimistic, as in the case of 22 UE countries the data for 2017 are higher comparing analogous data for 2011. Extremely progress has taken place in Hungary where the indicator nearly doubled. In one country - Portugal it did not changed, and in five countries it decreased. Spectacularly fall, more than $10 \%$, was observed in Ireland.

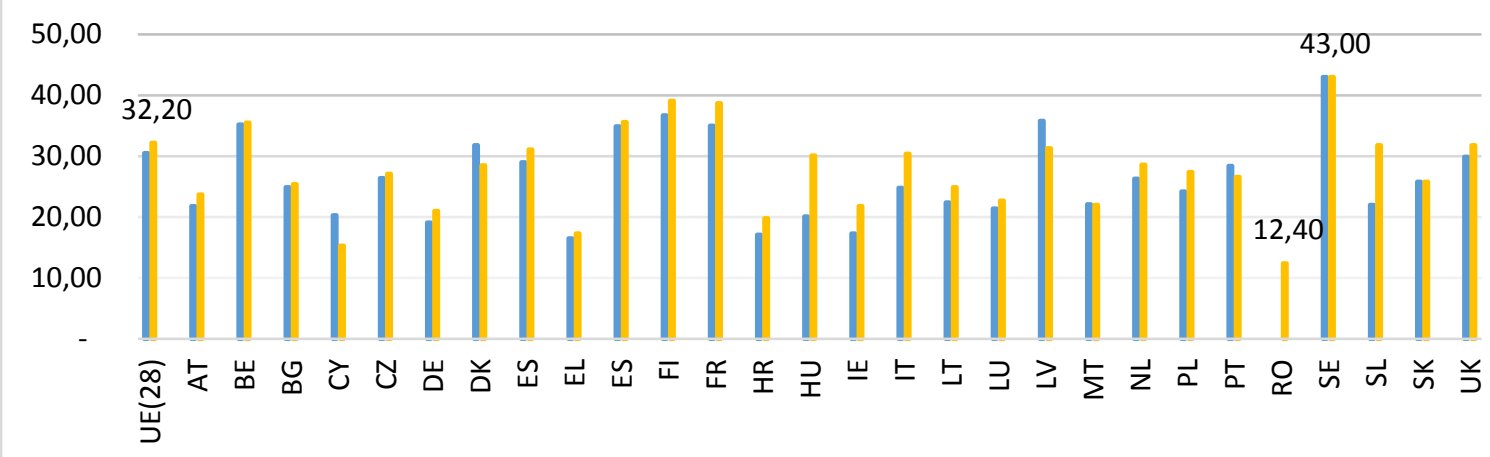

๑2011 2017

Source. http://eige.europa.eu/gender-statistics/dgs/indicator/wmidm_pol_parl_wwid_locpol

Figure 3. The share of women in municipal councils in 2011 and 2017 in EU (\%) 
The statistics on proportion of women in municipal councils looks much better in comparison to statistics on mayor positon. The average for UE proportion o of women in a such bodies is at $32 \%$. In 12 countries the indicator for 2017 is higher than $30 \%$ and in 18 women consist at least one quarter of members of council. The lowest proportion - $12 \%$ is for Romania, and in 3 other countries Cyprus, Greece, and Croatia the indicator is below $20 \%$ as well. Like in the case of mayor position, the quite high level of women share in municipal councils is observed in Sweden, Finland and France. It is worth to underline that between 2011 and 2017 the role of women in municipal councils proportion increased in 20 countries, in 2 it did not change an in 5 decreased.

As aforementioned, the statistics on women in top position for Poland are beneath the average for EU. The average share of women in group of gmina mayors for all types of gmina is amounted at $10,5 \%$.

The figure 4 shows the interesting phenomenon that the participation of women in group of gmina leaders does not depend on gmina type. A little smaller share in comparison to other types of gmina is observed in urban gminas. The underrepresentation of women on mayor positions is even more severe in urban gminas. It indicates that stereotype on the traditional role of women and men in rural areas versus more equal division of duties and rights in urban areas is no longer valid. As M. Stanny M (2014) and M. Wilkosz-Mamcarczyk, R. Różycka-Czas (2017) point - the society on rural areas has undergone very big multidimensional transformation.

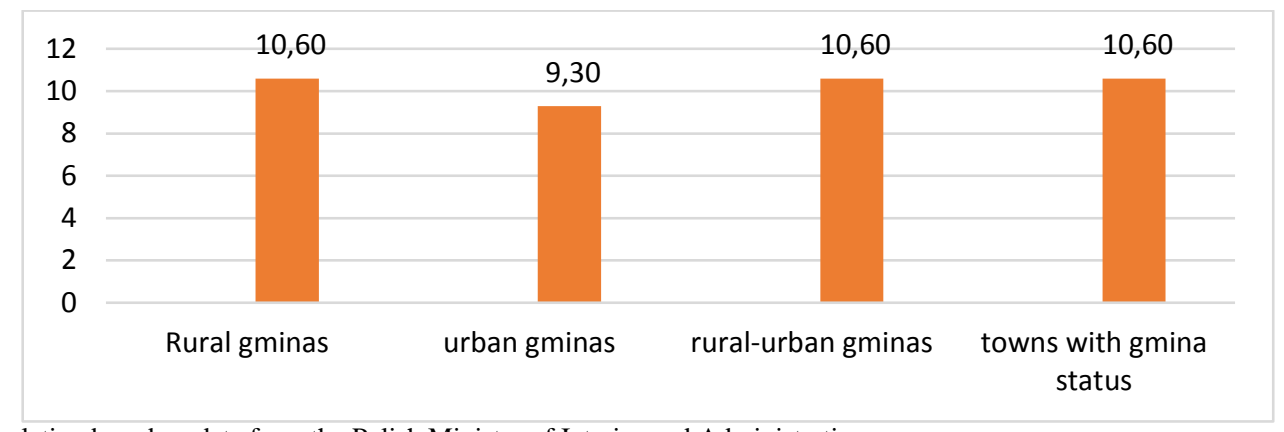

Source. Own calculation based on data from the Polish Ministry of Interior and Administration

Figure 4. The share of women on positon of a mayor in a group of gmina mayors in 2017 in Poland by the type of gmina (\%)

The scope presence of women on mayor position in rural gminas differs regionally (Figure 5). In north and west regions (voivodships) of Poland the participation of women at this position is about two times higher comparing to east (podlaskie voivodship) and south (malopolskie, slaskie voivodeships) Poland. According to I. Matysiak (2013) it can stemmed from massive migration to north and west parts of Poland after the Second World War. Such a relatively new created societies are more open to social innovations like participation of women in local governments.

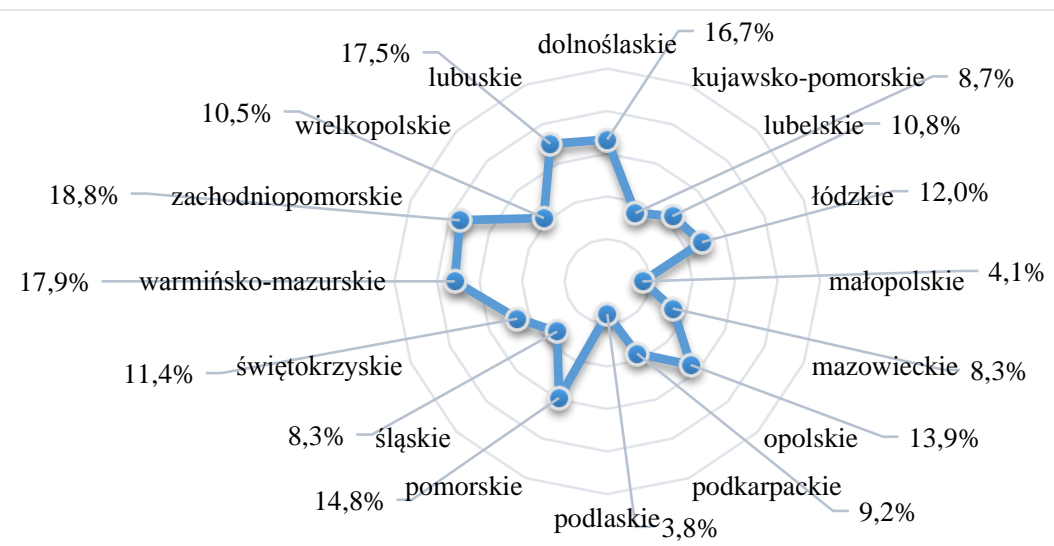

Source. Own calculation based on data from the Polish Ministry of Interior and Administration

Figure 5. The share of women on positon of a mayor in a group of gmina mayors in 2017 in Poland by the voivodship in 2017 (\%)

The very big difference between a proportion of women and proportion of men on position mayor of gmina is a puzzle. To find out the determinants of the phenomenon investigation was carried out. In table 1. the characteristics of $5 \%$ of rural gminas managed by women and $5 \%$ managed by men are confronted.

Data on the size of average gmina suggest that gminas headed by women are generally smaller regarding to area and the number of inhabitants as well. Only the average number of villages in examined groups is nearly the same.

Data showed that in woman headed rural gminas the share of women on deputy mayor position is much higher compared to rural gminas headed by men. So it suggests that men prefer to have a man as their deputy, whereas, women pay less attention to the sex of their closest collaborators. Position of Secretary of gmina office is dominated by women in men headed gminas however, in the women-led-gminas shares of women and men are equal. In the case of treasurer position the women prevail in both groups of gminas. It is partly the result of feminisation of accountancy profession in Poland. The very interesting result considers the position of a head of gmina council. There is not any woman on this 
position in women headed gminas and women hold that position only in $20 \%$ of men headed gminas. The share of women in gmina councils is generally rather low but higher in gminas with a man as a mayor. What is worth to underline, in women headed gminas proportion of women in a number of village mayors is quit high - at nearly $45 \%$ and higher by nearly 10 percentage points than in the other type of gmina. So it seems that in such gminas women are encouraged to apply for the higher position and voters feel more inclined to vote for women in comparison to gminas with less active women at village level. This supposition is entitled in the light of a very low participation of women in elections to government bodies. In the last election to local authorities in 2014, the share of women applying for position of mayor or its equivalent in other types of gminas was at very low level - 16.3\%. It indicates that the women are afraid to start in election and apply for the top position. It is somewhat surprising in the light of quite high participation of women in rural gminas' management that indicate qualification of women for running gmina. In the case of gmina council, the situation is much better, the share of women in a number of all candidates was estimated at 38\% (State Election Board, 2014). According to S. Michalska (2013) the advancement of women (rural women) position in politics is observed but in other areas is rather ambiguous.

Table 1. The size of gminas in groups by sex and proportion of women in their governing bodies

\begin{tabular}{|l|c|c|}
\hline \multicolumn{1}{|c|}{ Gminas' characteristics } & Gminas headed by women & Gminas headed by men \\
\hline Specification & & \\
\hline Population (average) & 6776 & 7171 \\
\hline Area (average) $\left(\mathrm{km}^{2}\right)$ & 101,2 & 112,4 \\
\hline Number of village administrators offices & 18 & 18,5 \\
\hline Share of women on position (\%) & & 15,4 \\
\hline - Deputy of mayor ${ }^{1}$ & 40 & 67,2 \\
\hline - Secretary of gmina office & 50 & 88,6 \\
\hline - Treasurer & 87,5 & 20 \\
\hline - Head of gmina council & 0 & 27,4 \\
\hline - Deputy of gmina council head & 30 & 27,7 \\
\hline Share of women in gmina council (\%) & 22,5 & 34,6 \\
\hline Proportion of women in a number of village mayors (\%) & 44,4 & \\
\hline
\end{tabular}

${ }^{1}$ only in 5 gminas headed by women and 39 gminas headed by men there is a position deputy of mayor

Source: Author's calculation based on sample data

\section{CONCLUSION}

The women participation in top positions in governing bodies of local communities in Poland is low. It indicates the existence of the severe problem with women promotion to the top positions in decision bodies in politics.

The luck of differences in women role in communities in rural and urban areas is a very interesting result. It suggests the important changes the rural society underwent. The other explanation is just opposite to that. As the most share of city inhabitants in third or second generation originates from village, it can prove the persistence of social patterns (new institutional economists' institutions).

Gminas managed by women are rather smaller than gminas administered by men due to area and population. In small local communities, the number of educated women is noticeably higher than educated men. Moreover, the characteristics of candidates to top positions - men and women - are more visible for voters in small societies. It can reduce the bias of some voters against female managers.

The bigger role of women in rural gminas was observed in the west part of Poland. In many gminas the position of women at the village level is higher than at gmina level. Probably, there is connection between the activity of women at village level and women position as mayor of gmina.

The investigation showed that in rural gminas women prevail in important back-office positions like main secretary of the gmina office and chief aaccountant. So, women are familiar with their gminas problems, are involved in management of them but as the statistics on voting to local authorities shows, they don't apply for the top positions. It seems that the concept of labyrinth can be applicable to the situation of women in decision making bodies in rural areas in Poland.

\section{REFERENCES}

1. Berheide, C. 1992. Women Still 'Stuck' in Low-Level Jobs. Women in Public Service 3. Fall, Vol. 1-4.

2. Boarini, R., Mira d'Ercole, M., Liu, G. 2012. Approaches to Measuring the Stock of Human Capital A Review of Country Practices. OECD Statistics Working Papers 04.

3. Bryant, G. 1985. The Working Woman Report: Succeeding in Business in the 80's. Simon \& Schuster (Paper) (October).

4. Danilowska, A. 2017. "Glass Ceiling” Problem in Rural Areas in Poland. Proceedings of the International Scientific Conference, Economic Sciences for Rural Development, Vol. 46, pp. 48-53. Latvia University of Agriculture, Jelgava, Latvia.

5. Eagly, A., Carli, L. 2007. Through the Labyrinth. The Truth about how Women Become Leaders, Harvard Business Review Press.

6. Eurostat 2017. Available at: http://ec.europa.eu/eurostat

7. Hegewisch, A., Hartman H. 2014. Occupational Segregation and the Gender Wage Gap: A Job Half Done. Institute for Women Policy Research, The George Washington University. 
8. Hymowitz, C., Schellhardt, T.D. 1986. The Glass-ceiling: Why Women Can't Seem to Break the Invisible Barrier that Blocks them from Top Jobs. The Wall Street Journal, 24 March.

9. Matysiak, I. 2013. Źródła i zasoby kapitału społecznego soltysów i soltysek w wybranych kontekstach lokalnych. [in:] Sawicka J. (ed.) Rynek pracy na obszarach wiejskich Mazowsza - perspektywa gender, Wydawnictwo SGGW, Warszawa. [In Polish]

10. Michalska, S. 2013. Tradycyjne i nowe role kobiet wiejskich (Traditional and New Roles for Rural Women). Wies $i$ Rolnictwo, Vo. 2 (159), pp. 124-138. [In Polish]

11. Morgan, M.S. 2015. Glass Ceilings and Sticky Floors: Drawing New Ontologies Economic. London School of Economics and Political Science Department of Economic History Working Papers 228.

12. Sirocka, A. (ed.) 2017. Za mało kobiet w zarządach. Fundacji Liderek Biznesu. Warszawa. [In Polish]

13. Stanny, M. 2014. Wieś, obszar wiejski, ludność wiejska - o problemach z ich definiowaniem. Wielowymiarowe spojrzenie. Wieś $i$ Rolnictwo, Vol. 1 (162), pp. 1-16. [In Polish]

14. State Election Board. 2014. Announcement on local authorised election statistics. Available at: http://pkw.gov.pl/425_Komunikaty_Komisarza_Wyborczego/1/16378_Informacje_statystyczne_na_temat_wyborow_Dane_stat ystyczne_dotyczace_wyborow_samorzadowych_zarzadzonych_na_dzien_16_listopada_2014_r_stan_na_godzine_12:00 (Accessed on 02/11/2017).

15. The European Institute for Gender Equality. 2017. Measuring Gender Equality in the European Union 2005-2015. Available at: http://eige.europa.eu/rdc/eige-publications/gender-equality-index-2017-measuring-gender-equality-european-union-2005-2015$\underline{\text { report }}$

16. Wilkosz-Mamcarczyk, M., Różycka-Czas, R. 2017. Rola kobiet w podtrzymywaniu tradycji miejsca na przykładzie gminy wiejskiej Brzeźnica. Problemy Drobnych Gospodarstw Rolnych, Vol. 1, pp. 71-80. Available at: http://pdgr.ur.krakow.pl/zasoby/98/2017_z2_a06.pdf. 